Chapter 10

\title{
Approaches for the Detection of Toxic Compounds in Castor and Physic Nut Seeds and Cakes
}

\author{
Keysson Vieira Fernandes and \\ Olga Lima Tavares Machado \\ Additional information is available at the end of the chapter \\ http://dx.doi.org/10.5772/52332
}

\section{Introduction}

The worldwide search for new fuel sources has grown during the last decades due to two main factors: the global concern about environmental issues and the high price of petroleum. Biodiesel is a type of biofuel that is already used in many countries, and its usage will most likely increase over the next few years. Biodiesel can be produced using different technologies and raw materials, such as vegetable oils, animal fats and microalgae oil. However, despite the wide range of oil sources for biodiesel production, vegetable oils are primarily used for this purpose. The choice of oilseed to be planted for biodiesel production depends on many factors, including the regional climate and soil conditions. The biodiesel industries in the US primarily use soybean oil, whereas in Europe, rapeseed is primarily used for biodiesel production. In tropical countries, biodiesel is produced from plants that grow in these tropical areas, such as palm, physic nut and castor bean.

In addition to biodiesel production using vegetable oils, the by-products generated at different steps during the production process have garnered increasing attention. Some of these by-products are generated in large amounts, making it both economically necessary and interesting to find a use for them. Currently, the residual cake, also known as the seed cake or press cake, has been shown to be a noteworthy by-product. The seed cake consists of the organic waste obtained during the oil extraction process by the pressing of seeds. Large amounts of residual cakes are generated during the oil extraction process. For example, for each ton of castor bean pressed for oil, a half-ton of cake is produced [1]. The residual cake can be used as fertiliser because of the macro- and microelements composition. Moreover, the protein content makes it useful as a component of animal feed. 
Several countries from South and Central America and Asia are attempting to use new oilseed sources for biodiesel production. Two of the oilseeds that are expected to be used for this purpose are the castor bean (Ricinus communis) and physic nut (Jatropha curcas). The oil properties of these seeds are well known, and many processes have been developed to produce biodiesel from these seeds. However, the large amount of residual cakes that are produced during the biodiesel production process and how to dispose of or use these cakes remain a problem. Both the castor cakes (castor bean) and Jatropha cakes (physic nut) have great potential for use as fertilisers. Castor cakes are rich in macroelements, including $\mathrm{N}, \mathrm{P}$, $\mathrm{K}, \mathrm{Na}, \mathrm{Mg}$ and $\mathrm{S}$, and were shown to supplement the nutritional requirements of plants, reduce the soil acidity by increasing the $\mathrm{pH}$, increase the carbon content, reduce the presence of nematodes and promote overall soil health [2]. Jatropha cakes are already used as green manure, also because of the N, P and K content [3]. It is expected that the castor and Jatropha cakes can be used as animal feedstock. These oilseed cakes are high in protein; therefore, their use as an animal food supplement is highly desirable. However, the presence of toxic substances in the seeds of $R$. communis and J. curcas restrict the use of the residual cakes as feedstock. Many detoxification processes have been described to render castor and Jatropha cakes edible. However, there is currently no recognized standard and safe methodology that could be used in the industry. Most of the detoxification processes developed have some negative aspects, such as high prices that are limiting for use on an industrial scale or the validation method. This second problem is the most difficult to solve because it is necessary that the detoxified cakes be safe to use as animal feedstock. A flawed method to detect toxins in the cakes could be very dangerous because a non-detoxified residual cake could be used to feed animals and may lead to death. In addition to toxic components, it was shown that allergenic proteins are also present in the seeds of R. communis[4] and J. curcas[5], and many methods for the detoxification of residual cakes have been shown to efficiently eliminate the toxins but not the allergens. For example, during the 1960s, a detoxified castor cake was commercialised in Brazil as Lex Proteic [6]; however, despite the absence of toxins, the allergens remained present in the castor cake. In this chapter, different methods to detect toxins from R. communis and J. curcas will be described.

\section{Ricinus communis toxins}

Castor bean seeds have long been known for their toxicity. They are the source of the most potent phytotoxin known, the protein ricin. Moreover, the toxic alkaloid, ricinin, is also found in the castor bean; however, this compound is different from ricin in that it is not as toxic and can easily be removed from the castor cake.

\subsection{Ricin}

The toxin, ricin, has been known since ancient times because of its use in criminal practices. According to Olsnes [7], in 1887, Dixon had hypothesised that the R. communis toxin was a protein, and Kobert confirmed this hypothesis in 1913. 
Ricin is a type 2 ribosome-inactivating protein (RIP) that is found exclusively in the endosperm of castor bean seeds. As a type 2 RIP, ricin is a dimeric protein comprised of an A chain $(32 \mathrm{kDa})$ and a $\mathrm{B}$ chain $(34 \mathrm{kDa})$ linked by a disulfide bond [8]. The ricin $\mathrm{A}$ chain (RTA) is responsible for the enzymatic activity of the protein. This N-glycosidase enzymatic activity removes a specific adenine, depurination, $\left(\mathrm{A}_{4324}\right)$ residue from a region of rRNA known as the $\alpha$-sarcin/ricin loop (SRL) (Figure 1).

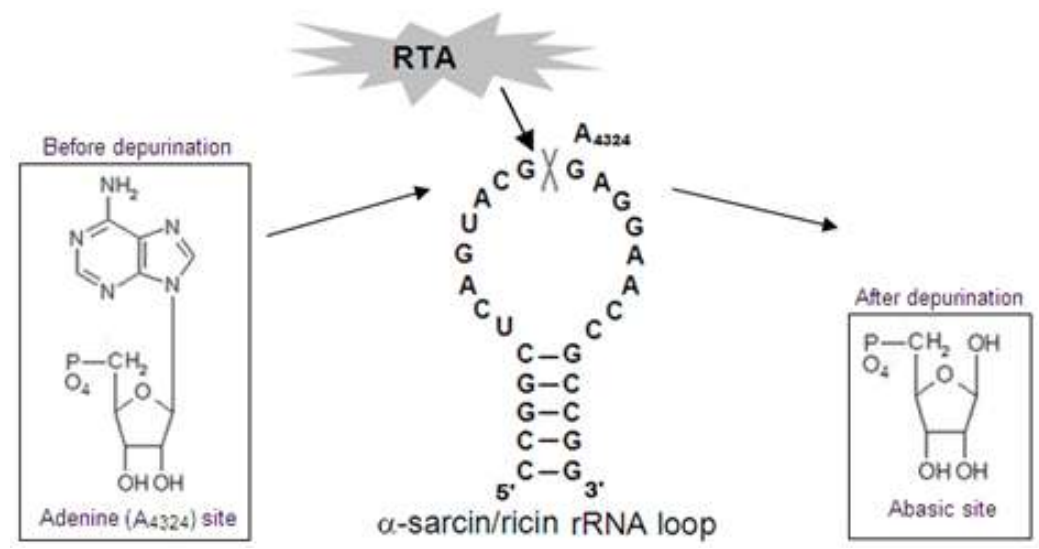

Figure 1. Thea-sarcin/ricin loop and the point of depurination by RTA N-glycosidase activity. The $\mathrm{A}_{4324}$ site before depurination by RTA is shown on the left where the intact nucleotide is present. On the right an after depurinationabasic site (without the adenine) is shown.

The absence of this adenine residue inhibits binding of the elongation factor, thereby stopping protein synthesis [9]. The B chain (RTB) is a lectin that binds to glycoproteins and glycolipids on the cell surface and cytosol and mediates the internalisation and intracellular translocation of the toxin $[10,11]$.

The ricin toxin is very efficient and a single molecule may inactivate 2,000 ribosomes per minute [12]. Because ricin can be used as a bioterrorism agent [13], many assays to detect ricin have been described. Some of these assays are highly accurate and can detect very low concentrations of the toxin. However, there is no standard methodology to use as a quality control for castor cake detoxification processes. Many methodologies to eliminate ricin toxicity from castor cakes have been described, and there are several promising processes when economic aspects are considered [14]. Therefore, to use castor cakes as animal feedstock, efficient methods to detect ricin toxicity after the detoxification process are needed to ensure quality control and safety before the material can be commercialised.

\subsubsection{Detection of ricin}

Because ricin can be used as a bioterrorism agent, the search for fast and sensitive detection methods began soon after the first studies describing the mechanism of action of ricin. The earliest proposed detection method was the enzyme-linked immunosorbent assay (ELISA) 
[15]. In this assay, rabbit anti-ricin antibodies (reduced IgG and Fab' fragments) conjugated with $\beta$-D-galactosidase was used. Using the rabbit anti-ricin Fab'- $\beta$-D-galactosidase complex, it was possible to detect as little as $4 \mathrm{ng} / \mathrm{mL}$ of ricin with the sandwich ELISA technique. However, less sensitivity was observed when this method was utilised for determining the amount of ricin added to rabbit body fluids. In this case, the lowest concentration of ricin that could be assayed was $40 \mathrm{ng} / \mathrm{mL}$. During the next two years, new methods based on radioimmunoassays were proposed $[16,17]$. These radioimmunoassays were very sensitive and could detect 50-100 pg RTA and 500 pg RTB; however, the sensitivity was reduced to intact ricin. The matrix used for these assays consisted of $0.1 \%$ sodium azide and $0.1 \%$ bovine serum albumin (BSA) in $0.05 \mathrm{M}$ sodium phosphate buffer. Limitations of these assays include the difficulties in handling radioisotopes and the long incubation period. Therefore, despite the high sensitivity of these assays, the drawbacks associated with radioimmunoassays make them less preferable than ELISA. Poli et al. [18] developed an enhanced colorimetric and chemiluminescent ELISA to detect ricin in biological fluids. This assay utilised an affinity-purified goat polyclonal antibody $(\mathrm{pAb})$ to adsorb ricin from the solution. The same $\mathrm{pAb}$ was then used to form a sandwich, and avidin-linked alkaline phosphatase was used for colour development. Enhancement of the colourimetric assay was obtained because of the increased biotinylated antibody content and a reduction in the dilution ratio of the avidin-linked alkaline phosphatase. This assay could detect $100 \mathrm{pg} / \mathrm{mL}$ ricin in phosphate-buffered saline (PBS), human urine and human serum. This sandwich assay could also be used with a chemiluminescence detection reagent; however, the quantitation was limited to a range of $0.1-1 \mathrm{ng} / \mathrm{mL}$ and was subject to greater variability compared to the colourimetric assay. An ELISA using monoclonal antibodies $(\mathrm{mAb})$ was performed to detect ricin in biological fluids [19]. This method was also based on the sandwich format using an anti-ricin $B$ chain $\mathrm{mAb}$ to adsorb ricin from the solution and an anti-ricin $\mathrm{A}$ chain $\mathrm{mAb}$ conjugated to peroxidase as the second antibody that is then used to form a sandwich. The peroxidase allows for colour development and measurement of optical density at $450 \mathrm{~nm}$. The sensitivity of this assay is $5 \mathrm{ng} / \mathrm{mL}$ and is lower than the sensitivity reported for the amplified and chemiluminescent immunoassays [18]. The ELISA is still used to detect ricin, and a commercial ELISA kit specific for ricin detection can be obtained [20]. However, ELISA has several disadvantages that prevent it from being the best method to detect of ricin. ELISAs consume too much time because of the washing steps involved and they also have limited throughput. ELISAs may also underestimate the actual ricin content in situations where antigen concentrations are high (hook effect) and specialised personnel are also required to perform the ELISAs.

To reduce the time necessary to assay for ricin, a method based on a fiber-optic sensor was developed [21, 22] and optimised [23]. A sandwich immunoassay scheme was used in which an anti-ricin IgG was immobilised onto the surface of an optical fiber. The limits of detection for ricin, as detected by laser-induced fluorescence, in a buffer solution and river water were $100 \mathrm{pg} / \mathrm{mL}$ and $1 \mathrm{ng} / \mathrm{mL}$, respectively. The complete assay can be performed in 20 minutes.

The first immunochromatography assay to detect ricin was performed using antibody anti A-Chain mAb with two distinct specificities. An anti-RTB mAb (1G7) was immobilised to a 
defined detection zone on a porous nitrocellulose membrane, whereas an anti-RTA mAb (5E11) was conjugated to colloidal gold particles that worked as the detection agent [24]. The ricin-containing mixture was added to the membrane and allowed to react with the mAb 5E11-coated particles. This mixture moved across the porous membrane by capillary action until it reach the extremity containing the anti-RTB mAbs, which bound to the particles of ricin that were attached to the gold-labelled anti-RTA mAbs. The detection limit of this assay was $50 \mathrm{ng} / \mathrm{mL}$ ricin in phosphate-buffered saline (PBS). This sensitivity could be enhanced further to $100 \mathrm{pg} / \mathrm{mL}$ with the use of a silver enhancer. The advantages of these gold particles were their superior mobility, decreased aggregation and commercial availability. An immunochromatography assay was also used to shown differences in ricin content among different castor bean cultivars [25]. All the ricin isoforms were detected in the range of 1 to $2.5 \mathrm{ng} / \mathrm{mL}$ in buffer.

In addition to using a better antibody for improved sensitivity, there was also a development regarding the technology of the solid phase surface of the immunoassay. The conventional microplate was exchanged for magnetic micro beads. Immunomagnetic (IM) assays to detect ricin were first used by Gatto-Menking et al. [26]. They used immunomagnetic electrochemiluminescence (IM-ECL) to detect ricin and other toxic agents, such as botulinus A, cholera $\beta$ subunit, ricin and staphylococcal enterotoxoid B. Antibody-conjugated magnetic micro beads were used to capture the target toxins and ruthenium trisbipyridal chelate-labelled antibodies were used as the reporter. High sensitivity levels were obtained for all the tested toxins. All IM-ELC assays could be performed in a maximum combined incubation and assay time of approximately 40 minutes, and the sensitivity to ricin was $5 \mathrm{pg} / \mathrm{mL}$. Some years later, an enhanced ECL assay had a detection limit of $0.5 \mathrm{pg} / \mathrm{mL}$ for ricin in PBS [27]. The same study demonstrated the detection of ricin by fluorogenic-chemiluninescence (FCL), and the sensitivity was $1 \mathrm{ng} / \mathrm{mL}$. Advantages of these micro beads were due to their large surface area (Figure 2) that leads to enhanced sensitivity, to free moving microspheres coated with antibody that accelerates the reaction rates and reduces the assay time, and to easy detection using a simple magnetic field. Both the FCL and ECL had similar formats, except that the FCL used alkaline phosphatase as the label and detected the ricin through the measurement of fluorescence, whereas the ECL used ruthenium-trisbipyridal as the label and detected the ricin through photoemission. For a magnetoelastic surface sensor instead of microspheres, the detection technology was a sandwich immunoassay on the sensor surface. Biocatalytic precipitation was then used to cause a change in mass, which resulted in a change in the resonance frequency that allowed for quantitation of ricin at a detection limit of $5 \mathrm{ng} / \mathrm{mL}$ in aqueous media, such as water, blood or serum [28]. This magnetoelastic sensor had a sensitivity that was comparable to the ELISA; however, this assay had a much lower cost, was disposable and had a relatively quick analysis time.

The search for an assay to detect several toxins simultaneously led to the use of array systems. Three different toxins, ricin, SEB and Yersinia pestistoxin, were detected using a planar array immunosensor equipped with a charge-coupled device (CCD) [29]. This was a disposable and simple sensor array coated with different antibodies that were detected through the CCD. This planar array platform gave a detection limit of $25 \mathrm{ng} / \mathrm{mL}$ ricin, $5 \mathrm{ng} / \mathrm{mL}$ SEB 
and $15 \mathrm{ng} / \mathrm{mL}$ Y. pestis, based on a goat anti-ricin antibody in PBS containing $0.05 \%(\mathrm{v} / \mathrm{v})$ Tween-20. This detection method allowed for multiple sample analysis using a minimum amount of sample and simultaneous analysis that was inclusive of the controls. An antibody microarray biosensor for the rapid detection of both protein and bacterial analytes under flow conditions was developed using a micrometer-sized spot [30]. Using a non-contact microarray printer, biotinylated capture antibodies were immobilised at discrete locations on the surface of an avidin-coated glass microscope slide. The slide was fitted with a six-channel flow module that conducted analyte-containing solutions over the array of capture antibody microspots. Detection of the bound analyte was subsequently achieved using fluorescent tracer antibodies. The pattern of fluorescent complexes was interrogated using a scanning confocal microscope equipped with a $635-\mathrm{nm}$ laser. The assays were completed in 15 minutes, and ricin detection was demonstrated at levels of $10 \mathrm{ng} / \mathrm{mL}$. The detection limits for the other analytes were also relatively low. These assays were very fast compared to the previously published methods for measuring antibody-antigen interactions using microarrays (minutes versus hours). In addition, whereas other antibody microarray assays can detect specific proteins present in complex mixtures, this method could detect proteins and bacteria simultaneously. Recent improvements in the microarrays to detect ricin and other biological agents have been described. A method that used a bioanalytical platform that combined the specificity of covalently immobilised capture probes with dedicated instrumentation and immuno-based microarray analytics was able to detect ricin at $0.5 \mathrm{ng} / \mathrm{mL}$ in PBS and 1-5 ng/mL in milk [31]. However, despite the high sensitivity compared with the other array methods, this assay took approximately 90 minutes.

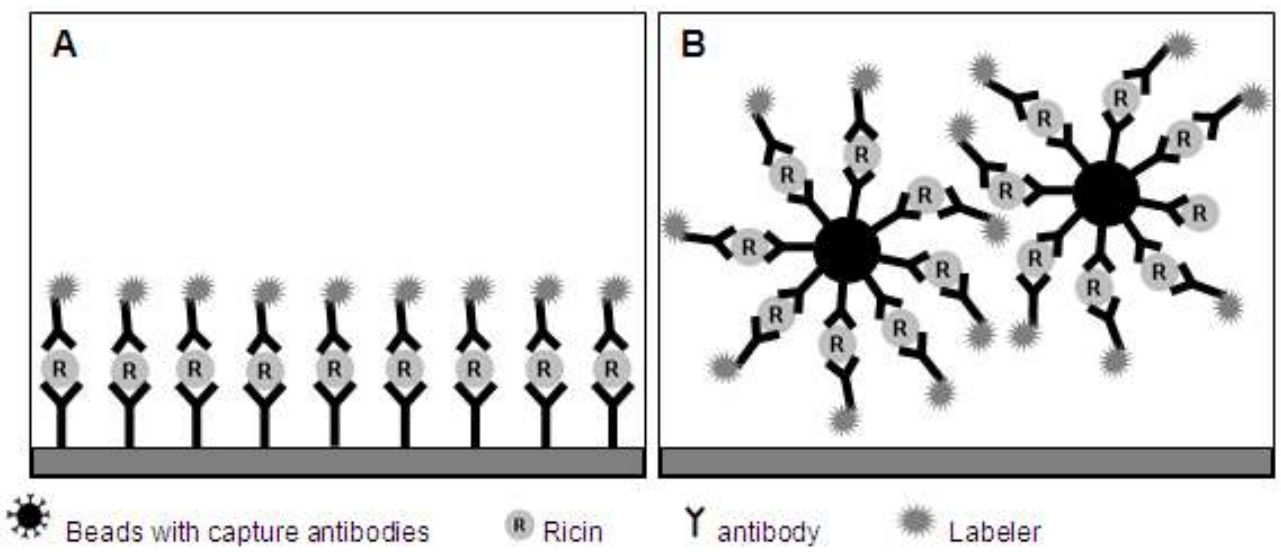

Figure 2. Comparative schematic of two immunoassays used to detect ricin. A) Sandwich ELISA. B) Microbeads immunoassay. The recorder antibody can be linked to different labeler molecules, as Ruthenium, alkaline phosphatase or horsehadish peroxidase.

Sano et al. [32] developed a method to detect antigens that combined the specificity of immunological analysis with the exponential amplification of PCR. This immuno-polymerase 
chain reaction (IPCR) was an interesting method to monitor the presence of ricin in samples [33]. A schematic representation of this method is shown in Figure 3.

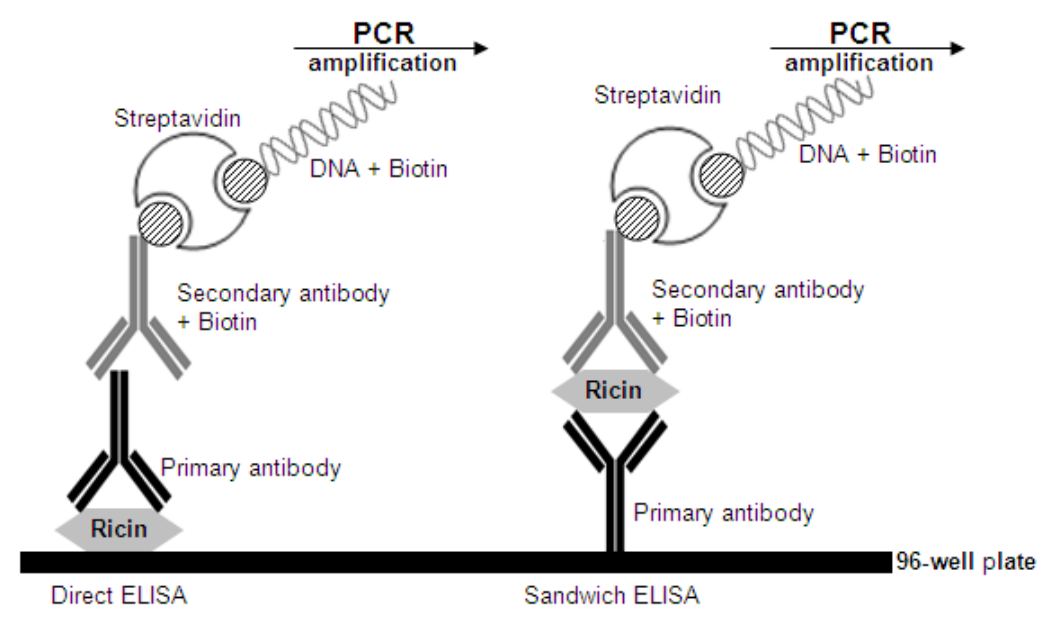

Figure 3. Schematic representation of the IPCR detection of ricin using both direct and sandwich ELISA to capture and report the toxin. The biotin-streptavidin interaction plays the bridge role between secondary antibody and the reporter DNA, which is amplified by PCR.

Ricin was dissolved at different concentrations in PBS, and detection was performed revealing a detection limit of $10 \mathrm{fg} / \mathrm{mL}$. The assay was then performed with ricin dissolved in human serum revealing a detection limit of $0.5 \mathrm{fg} / \mathrm{mL}$. The method has also been used for postintoxication evaluation of the biological half-life of ricin. IPCR analysis of sera from mice fed ricin showed that the toxin was rapidly sequestered from the sera (30 minutes) with a halflife $\left(t_{1 / 2}{ }^{\alpha}\right)$ of 4 minutes [34]. The time required to complete the entire IPCR process is 9 hours. Compared with conventional immunological methods, IPCR requires a greater amount of time because of the PCR itself and the post-PCR analysis. Moreover, the use of more expensive reagents and the increased reagent consumption make this technique less attractive than conventional immunological methods. However, these limitations are counterbalanced by greater sensitivity ( 8 million times greater than conventional ELISA), enabling a broader range of applications.

In recent years, highly sophisticated mass-spectrometry (MS)-based methods for the detection and quantification of ricin have been developed. It was shown that ricin could be unequivocally identified by liquid chromatography-electrospray (LC-ES) MS/MS experiments with reduced, cysteine-derivatised, trypsin-digested material [35]. It was also shown that MALDI-MS could be used to detect intact ricin and to screen samples for ricin peptides. The amount of crude sample required was a few milligrams containing less than $5 \%$ ricin. According to the authors, the selection of a few marker peptides from the A and B chains can be used as a method to improve the sensitivity and efficiency of this method. A method 
combining immunocapture and analysis by matrix-assisted laser desorption/ionisation timeof-flight mass spectrometry (MALDI-TOF MS) for ricin detection was also described [36]. Ricin samples were applied to magnetic spheres coated with a monoclonal anti-B-chain antibody. After acidic elution, tryptic peptides of the A and B chains were obtained by accelerated digestion with trypsin in the presence of acetonitrile. Three of the 20 peptides obtained were used for ricin detection by MALDI-TOF MS. This assay had a limit of detection estimated at $50 \mathrm{ng} / \mathrm{mL}$, and the result could be obtained in approximately 5 hours. These results are not as exciting compared to other more sensitive and faster methodologies; however, an interesting feature is that MS detection provides increased specificity because of the simultaneous monitoring of several characteristic ricin-specific peptides. Furthermore, the possible miniaturisation of MALDI-TOF technology suggests that the assay could be adapted for use with a portable mass spectrometer. A recent study described the combination of a multiplex-immunoaffinity purification approach followed by MALDI-based detection for the simultaneous identification of different toxins, including ricin [37]. Selected antibodies against each toxic agent allowed for the specific and simultaneous capture of these toxins. The toxins were subsequently identified by MALDI-TOF MS following a tryptic digest, and after an assay time of 8 hours, the ricin could be detected at a minimum of $200 \mathrm{ng} / \mathrm{mL}$. The time requirement and detection limit were not satisfactory for this assay; however, ricin could be detected in complex matrices, such as milk and juice.

Aptamers are artificial nucleic acid ligands that can be generated against amino acids, drugs, proteins and other molecules. They are isolated from complex libraries of synthetic nucleic acids by an iterative process of adsorption, recovery and reamplification. Because of their high thermostability when compared with antibodies, aptamers have potential applications in analytical devices, including biosensors, and as therapeutic agents [38]. Assays for protein identification and quantitation were developed and applied to ricin detection [39, 40]. A multiplex aptamer microarray was generated by printing an anti-ricin RNA aptamer onto either streptavidin (SA)- or neutravidin (NA)-coated glass slides. The limit of detection in a sandwich assay format after optimisation studies was $15 \mathrm{ng} / \mathrm{mL}$ in PBS. This assay was also used to detect other proteins and showed satisfactory results. Capillary electrophoresis (CE) has been shown to be a viable alternative to traditional immunoassays when coupled with laser-induced fluorescence detection. Haes et al. [41] demonstrated that capillary electrophoresis could be used to detect ricin by monitoring its interaction with a fluorescently tagged aptamer under non-equilibrium conditions. The quantitative response revealed a detection limit as low as $14 \mathrm{ng} / \mathrm{mL}$. This study also revealed that the presence of nucleases in the sample leads to a slight decrease in the ability of the aptamer to detect ricin; however, it is still possible to detect the toxin at very low concentrations. This assay can be performed in less than $10 \mathrm{mi}-$ nutes, consumes minimum quantities of material, and generates a low amount of waste.

Liquid-crystal (LC) based sensors that can be used as rapid and effective detection technologies have attracted a significant amount of attention in recent years [42], and their utility regarding ricin detection has previously been demonstrated [43]. This method relied on the use of LCs 5CB to amplify and report the presence of ricin captured by an affinity ligand. 
One merit of this approach is that the ricin can be imaged on chemically functionalised surfaces and transduced into an optical signal. The optical signal caused by the orientational transition of the LCs could easily be identified with polarised light microscopy. However, despite the success of the LC-based sensor, which did not use complex instrumentations and did not involve any labelling steps, the limit of detection of $10 \mu \mathrm{g} / \mathrm{mL}$ was not as good compared to other methods. Similar to other assays, this interesting technology must be improved to become among the most sensitive methods for ricin detection.

Despite the many methods to detect the presence of ricin, the detection of the toxin in castor cakes subjected to detoxification is not performed in a standard manner. Anandan et al. [44] used different physical and chemical treatments to detoxify castor cakes, and the ricin content was determined based on electrophoretic analysis. They reported that ricin bands did not appear in SDS-PAGE samples of autoclaved (15 psi, 60 minutes) and lime treated (40 $\mathrm{g} / \mathrm{kg}$ ) castor cakes. Solid-state fermentation by Penicillium simplicissimum also reduced the ricin content when fermented castor waste samples, which were not the cake but an extremely alkaline waste, were evaluated by electrophoresis [45]. However, this detection method has many disadvantages compared to the described techniques. The first disadvantage is the low sensitivity of the method. A lower ricin concentration that remains lethal cannot be detected; therefore, if electrophoresis is used as the detection method, another more sensitive assay needs to be performed to validate the detoxification process. Another problem is related to the long assay time and specialised personnel required to perform these analyses and the necessity of performing a Western blot assay to confirm the identity of ricin.

The greatest problem that affects not only electrophoresis, but also all the ricin detection methods described in this chapter, is the inability to detect the biological activity of the toxin. Each proposed assay can detect the presence of ricin at minimal concentrations and many of these are able to do so in a very sensitive and specific way; however, they cannot determine whether the toxin is biologically active. To validate the castor cake detoxification processes, it is important to be able to detect the biological activity of ricin. This is because some of the described toxin inactivation processes can be related to modifications in the active site of the enzyme, and although ricin may be present in processed cake, it may be not active and the product would be safe to use in animal feed.

\subsubsection{Detection of ricin biological activity}

The first method of detecting ricin activity was based on measuring the inhibition of protein synthesis in a rabbit reticulocyte cell-free system mediated by toxic tryptic peptides from ricin [46]. The method was justified because of the long period of time required to observe intoxication symptoms in animals. It was reported that similar to the native protein, toxic ricin peptides could inhibit protein synthesis in a cell-free system. This information reinforces the necessity for assaying ricin biological activity after subjecting the castor cake to detoxification processes.

The ability of the RIPs in inhibit protein synthesis can be monitored with in vitro translation assays using the rabbit reticulocyte lysate system [47, 48]. One disadvantage of these assays is the use of a multistep procedure to determine the RIP activity by measuring the incorpo- 
ration of radioactive amino acids after the addition of mRNA or polysomes to the system. Therefore, an in vitro transcription/translation single-step assay utilising the luciferase bioluminescence detection system was described to characterise mistletoe lectin I (ML-I) and ricin [48]. The in vitro translation assay couples the following reactions into one step: (1) DNA consisting of a coding sequence is transcribed into messenger RNA; and (2) RNA is then translated into proteins in a cell lysate (product of burst cells) that provides ribosomes and other necessary components. When the translated protein is luciferase, the fluorescence acts as a protein synthesis indicator, and the absence of fluorescence indicates that protein synthesis was inhibited (Figure 4). The inhibition of luciferase synthesis by ricin was achieved when the toxin was used at a minimum concentration of $30.2 \mathrm{pM}(\sim 800 \mathrm{pg} / \mathrm{mL})$. The RIP specificity of this assay was proved using formycin 5 -monophosphate (FMP) as a specific inhibitor of RIP activity. The limit of detection is comparable to those obtained with other methodologies, and the assay also showed the toxic activity of ricin.

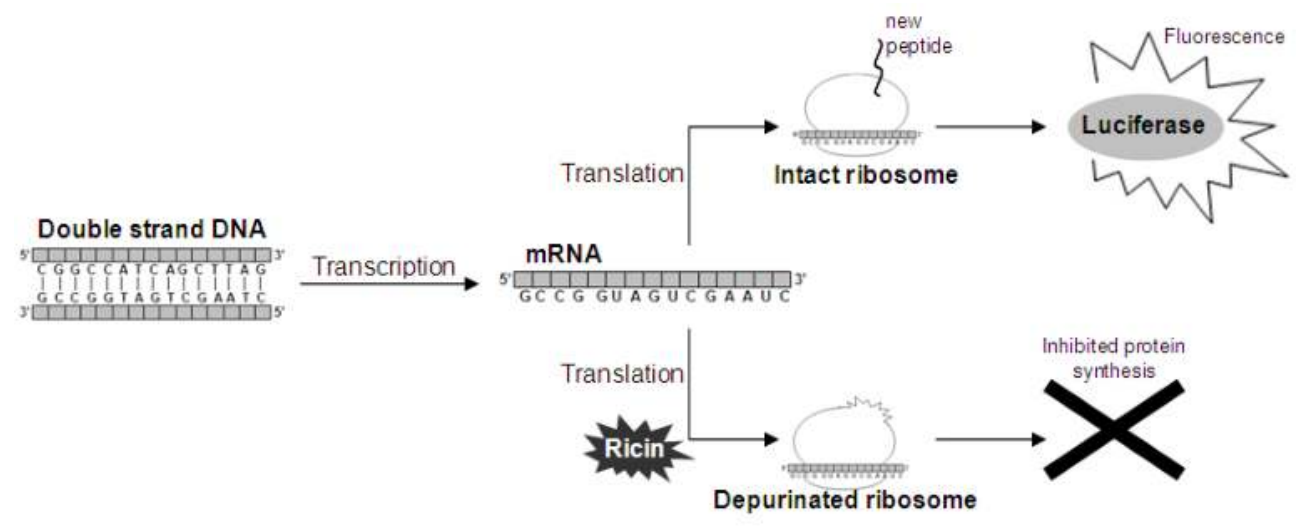

Figure 4. Translation and protein synthesis inhibition by ricin. The assays based on this activity detect the presence of an specific reporter protein. In the presence of the protein can not be synthesized. The luciferase is the best described example for this kind of assay.

The inhibition of protein synthesis was also the target of a method to detect ricin in a "wellin-well" device [49]. The miniaturised system presented a mechanism to supply nutrients continuously and remove by-products, leading to higher protein expression yields and larger detection signals. This method showed a detection limit of $0.3 \mathrm{ng} / \mathrm{mL}$ ricin. The nestedwell device was also used for measuring the toxicity of ricin after physical or chemical treatment. The good results obtained with inactivated ricin make this method a good choice for use in castor cake detoxification processes.

The N-glycosidase activity removes an adenine residue from the $\alpha$-sarcin/ricin loop of rRNA. The removed adenine can be used as a positive indicator of biologically active ricin. The most common method for quantifying free adenine in a variety of applications is the detection of fluorescent-derivatised adenine by HPLC [50]. To detect ricin activity based on 
rRNAdepurination, a high-throughput, enzyme-based colorimetric adenine quantification assay was developed [51]. The key step of this assay is the conversion of adenine to AMP and concurrent release of pyrophosphate from PRPP. Pyrophosphate is then cleaved to phosphate by inorganic pyrophosphatase. To enhance the signal, the AMP formed is converted by 5 -nucleotidase to adenosine and inorganic phosphate, finally resulting in three phosphates for each adenine. Inorganic phosphate was quantified by a modified procedure with a commercially available kit. All four enzyme reactions of the assay, including colour development, occur simultaneously in approximately 15 minutes inside the same reaction tube, and the rate of adenine released by the commercially obtained RTA was determined to be 43 pmol adenine/pmol RTA per hour.

Recently, several methods using electrochemiluminescence (ECL) to detect ricin activity were also developed $[52,53]$. First, a deadenylation assay using paramagnetic beads could detect ricin in crude extracts $[52,54]$. Synthetic biotinylated RNA substrates were cleaved by the combined actions of the ricin holotoxin and a chemical agent, N,N'-dimethylethylenediamine. The annealing of the product with a ruthenylatedoligodeoxynucleotide resulted in the capture of ruthenium chelate onto magnetic beads, enabling the electrochemiluminescence (ECL)-based detection of RNA N-glycosidase activities of toxins. Compared to ECL immunoassays [26], the ECL activity assay presented lower sensitivity, reaching a detection limit of $100 \mathrm{pg} / \mathrm{mL}$. The disadvantage of the ECL immunoassay compared to the ECL activity assay is that the antibodies recognise surface features of the proteins (epitopes) that may be unrelated to any enzymatic activity or other mechanism of toxicity. Therefore, it may be possible for inactive protein toxins to cause positive signals in these immunoassays resulting in an over-estimation of the threat. The plate-based assay unlike the bead-based assay, included wash steps that enabled the removal of food particles, thereby maximising the matrix effects and improving the limits of detection. The limits of detection for ricin in apple juice, vegetable juice, and citrate buffer using the bead-based assay were $0.4,1$, and 0.1 $\mu \mathrm{g} / \mathrm{mL}$, respectively. By contrast, the limits of detection for ricin using the plate-based assay were $0.04,0.1$, and $0.04 \mu \mathrm{g} / \mathrm{mL}$ in apple juice, vegetable juice, and citrate buffer, respectively. These data suggest that the plate-based assay is the best method for detecting ricin activity by ECL.

The ricin detection methods based on adenine liberation and direct infusion electron spray ionisation mass spectrometry have been shown to provide rapid, selective, and sensitive detection of various peptides and small nucleic acids, and these methods should provide a sensitive method for the real-time analysis of RIP enzymatic activity by monitoring adenine release. Therefore, high-performance liquid chromatography (HPLC) and selected ion monitoring mass spectrometry (MS) were used to develop a quantitative assay for adenine release from a synthetic RNA substrate by the ricin A chain [55]. The sensitivity of this MS assay made it possible to measure RIP activity at approximately $0.6-$ to $600 \mathrm{ng} / \mathrm{mL}$. A more specific assay to detect ricin by MS was developed by Becher et al. [56] in which they used an anti-B chain mAb immobilised on magnetic beads to capture the toxin. Ricin toxicity was measured through quantification of the free adenine by HPLC-MS. The immunoaffinity step 
combined with enzymatic activity detection led to a specific assay for the entire functional ricin protein with a lower limit of detection of $100 \mathrm{pg} / \mathrm{mL}$.

When mass spectrometry was used to detect ricin activity, a combination of three techniques, all performed on the same sample, provided a sensitive and selective analysis of ricin isolated from a food or clinical sample and measured the activity of the toxin [57]. First, ricin was isolated from abundant proteins in a food or clinical sample, such as milk, apple juice, serum or saliva through immunoaffinity capture on antibody-coated beads. Second, the activity of ricin was examined through interaction of the toxin with a DNA substrate that simulated the in vivo target of the toxin. The DNA substrate was analysed by MALDI-TOF MS, allowing for sensitive and selective measurements of the depurination of the DNA substrate. Finally, in the third step, the ricin was subjected to tryptic digestion, and the resulting tryptic fragments were analysed by liquid chromatography tandem mass spectrometry (LCMS/MS), allowing for direct examination of the composition of the ricin protein based on the molecular weight change caused by the depurination activity. The limit of detection was approximately $300 \mathrm{ng} / \mathrm{mL}$.

The mass spectrometry based methods for detecting ricin activity through monitoring adenine liberation have some disadvantages that make them not suitable for use in the validation of the detoxification processes of the castor cakes. These disadvantages include complications regarding the handling of mass spectrometers and the interpretation of results that requires highly specialised personnel. Another problem is that adenine liberation may not be the most efficient method to detect biologically active ricin because depurination activity is not a unique mechanism involved in ricin toxicity. It was previously shown that non-cytotoxic RTA mutants could depurinate ribosomes in yeast cells without the occurrence of cell death and apoptosis signals [58].

Toxicology assays to detect ricin based on the activity against animals could be the best way to evaluate the efficiency of castor cake detoxification processes because of the desire to use this by-product as animal feedstock. However, despite the ethical questions surrounding the use of in vivo models, there are also economic and infrastructure problems. Housing live animals to evaluate toxic activity requires physical space and maintenance. Therefore, an in vitro assay based on the cytotoxicity against Jurkat clone E6-1 cells was developed to detect ricin in different beverages, such as orange juice, coffee and soda, and food matrices, such as milk, milk baby formula and soy baby formula [59]. After incubating the cells in a 96-well plate with ricin, the culture was maintained overnight at $37^{\circ} \mathrm{C}$ and $5 \% \mathrm{CO}_{2}$. Aliquots of each treated well were collected and assayed for lactate dehydrogenase (LDH) activity with a colorimetric assay. $\mathrm{LDH}$ was released from the cytosol upon cell damage and was positively correlated with cell death. Ricin was detected in each assayed matrix with a sensitivity of $10-100 \mathrm{pg} / \mathrm{mL}$. It was also shown that ricin cytotoxicity could be inhibited by the administration of an anti-ricin neutralising antibody that works as a qualitative mechanism. Other cell culture assays were also recently developed. Sehgal et al. [60] used Vero cells (Chlorocebus sabaeus kidney cells) to evaluate the cytotoxicity of different ricin isoforms. They showed that the isoforms R-I, R-II and R-III were detected at a minimum concentration of $20 \mathrm{mg} / \mathrm{mL}$, $10 \mathrm{ng} / \mathrm{mL}$ and $2 \mathrm{ng} / \mathrm{mL}$, respectively. Subsequently, they showed that the cytotoxicity of the 
three isoforms is time dependent and that the R-III isoform is more glycosylated than the other two isoforms [61].

The possibility of using cell culture models to evaluate ricin toxicity by colorimetric assays, such as the LDH assay, seem to be a good idea for use as a biological test to determine the efficiency of the castor bean cake detoxification process. It was reported that solid-state fermentation (SSF) reduced the ricin levels in castor bean alkaline waste from Petrobras (the national petroleum company of Brazil) during the biodiesel production process [45, 62]. This was determined by molecular exclusion chromatography and electrophoresis. To verify the biological activity of ricin after SSF at different time intervals, an in vitro assay using the Vero cell line was performed [63]. Using this methodology, it was verified that after 24 and 48 hours of fermentation, the cell culture showed slight growth inhibition. The waste was completely detoxified after only 72 hours of fungal growth. The cell incubation period with the protein extract from the fermented waste was 24 hours, and cell death was determined by cell counting with an optical microscope and measurement of LDH activity using a colorimetric assay (Figure 5).

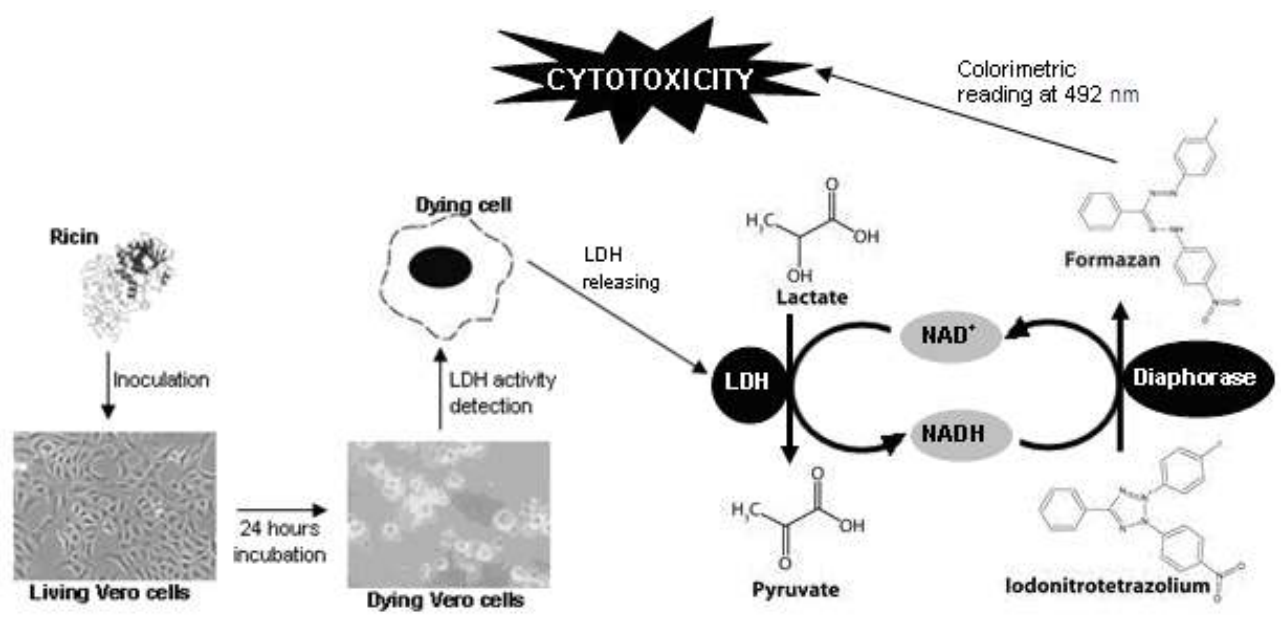

Figure 5. Cytotoxicity assay using Vero cells. The cell monolayer in a 24-well plate was incubated with ricin for 24 hours. An aliquot from each well was removed and mixed with the assay solution for LDH activity determination. The formazan formed a salt that caused the solution to turn red. The cytotoxicity is measured based on the intensity of this colouration.

When the cell counting and LDH assays were compared to determine the cytotoxicity of ricin against Vero cells, it was reported that both methods are efficient and detected ricin at a minimum concentration of $10 \mathrm{ng} / \mathrm{mL}$ [64]. After adjusting the method to detect the purified protein, they used the Vero cell cytotoxicity assay to evaluate the following two castor cake detoxification processes: SSF using Aspergillus nigerand treatment with calcium compounds. The results with the Vero cells showed that both treatments were efficient in eliminating ricin toxicity from the castor cake. 


\section{Jatropha curcas toxins}

Two main toxic components are present in the physic nut plant, the ribosome-inactivating protein, curcin, and phorbol esters. Among these toxins, the phorbol esters are the most dangerous toxic components in J. curcasand limit the use of Jatropha cake in animal feed.

\subsection{Curcin}

Curcin $(28.2 \mathrm{kDa})$ is a type 1 RIP that is found in Jatropha curcas seeds [65] and leaves [66]. Curcin is different from ricin in that it is a monomeric protein with $\mathrm{N}$-glycosidase activity but lacks a lectin chain [67]. Therefore, this protein is much less cytotoxic than ricin and other type 2 RIPs because it cannot enter cells by binding to sugar residues. Despite the fact that curcin is less toxic than phorbol esters, it has been reported to be toxic to some animals, including sheep, goats, chickens and calves and also to humans [68-72]. Because of the low toxicity of curcin, there are not many detection methods specifically for this toxin. The most common detection methods are the inhibition of translation in rabbit reticulocyte lysates and the measurement of $\mathrm{N}$-glycosidase activity [67]. Although there are few publications describing the different methods to detect curcin, many of the assay methods for ricin could be applied to other RIPs, including curcin.

\subsection{Phorbol esters}

Phorbol esters (PE) are polycyclic compounds in which two hydroxyl groups in neighbouring carbons are esterified to fatty acids, and these substances are present in many different plants, including J. curcas [73]. The PE molecules are dependent on a tetracyclic diterpene carbonic structure termed tigliane. The different hydroxylation points of tigliane determine the different varieties of PE and their toxicity [74].

The PEs and their different derivatives are known for their tumour induction activity. They activate protein kinase $\mathrm{C}$ (PKC), which plays a critical role in signal transduction pathways and regulates cell proliferation [75]. By contrast, it was reported that some types of PEs could induce apoptosis [76].

Several detoxification processes used to eliminate PEs from Jatropha cake have been previously described [14], and some of the existing detection methods were used to confirm the effectiveness of these processes.

\subsubsection{Detection of phorbol esters}

Many of the phorbol ester detection methods are related to using Jatropha cake as animal feedstock, which are different from ricin containing cakes that can be used as bioterrorism agents. Therefore, there are few techniques for PE detection compared to ricin detection methods.

The determination of irritant activity caused by phorbol esters was first demonstrated by Adolf et al. [77]. The irritant activity of PE isolated from different Jatropha species was as- 
sayed in rat ears, and the irritant dose 50 for J. curcas PEs was $0.02 \mu \mathrm{g} /$ ear. More than two decades later, in vivo studies of PE toxicity are still performed in rats and mice [78, 79]. Jatropha cake subjected to alkali and heat treatments to reduce the PE level was used to feed rats, and several clinical aspects and the mortality rate were compared with rats fed untreated cake [78]. Using these rodents to detect PE toxicity was effective because even the treated Jatropha cakes with low levels of PE $(8.1 \mathrm{mg} \%)$ caused rat mortality after 11 days. The acute toxicity of PE was determined in Swiss Hauschika mice by intragastric administration [79]. The $\mathrm{LD}_{5}$ and $\mathrm{LD}_{95}$ were 18.87 and $39.62 \mathrm{mg} / \mathrm{kg}$ body mass, respectively. These toxicity assays efficiently detect PE toxicity; however, they are problematic because of maintaining and sacrificing many animals due to the large quantities of residual cake that is generated.

The most commonly used method to detect and quantify PE from Jatropha curcas is reverse phase - high-performance liquid chromatography (RP-HPLC). This method was standardised to detect PE in different provenances of J. curcas, and it was the first method to identify the absence of PE in seeds from Papantla, Mexico [80, 81]. The protocol established in this study has been optimized [82] to show the presence of PE. The limit of detection of PE by RP-HPLC analysis is approximately $4 \mu \mathrm{g}$, as described by Devappa et al. [83]. RP-HPLC detection has been used by many researchers to determine the efficiency of Jatropha cake detoxification processes, including hydrothermal processing techniques, solvent extraction, solvent extraction plus treatment with $\mathrm{NaHCO}_{3}$, ionizing radiation, heating, bio-detoxification and surfactant solution extractions [84-88]. This technique can also be used to identify different PE species present in J. curcas, and the difference in PE composition among Jatropha seeds from different regions, cultivars and assessments [83, 89-91]. HPLC was also used to determine the PE content in oil extracted from the seeds [92-94].

Similar to ricin detection methods, the biological activity of phorbol esters must to be assayed to guarantee the efficiency of the Jatropha cake detoxification processes. Because Jatropha cake is used as feedstock, quality control of detoxification processes is often performed using live animals, such as rats [77, 79]), sheep [95], pigs [96] and fish [97, 98]. With a few exceptions, this type of biological activity control is usually preceded by RPHPLC detection and quantification of PEs. Therefore, it remains necessary to continue using RP-HPLC and sacrificing animals to detect the presence and biological activity of PEs because toxicity evaluation using live animals is not the best method for use on a large scale. Other biological tests have previously been described for assaying PE toxicity, and some of these assays are very sensitive and simple to perform on a large scale.

Earlier reports regarding J. curcashave described molluscicidal activity of the seed extracts against Oncomelania quadrasi [99] and of the root extracts against Bulinus truncatus [100]. However, the most well-established molluscicidal test using snails was described by Liu et al. [101]. They tested several plant extracts, including J. curcas phorbol esters in methanol, against three schistosome vector snails: Oncomelania hupensis, Biomphalaria glabrataand Bulinus globosus. The 4- $\beta$-phorbol-13-decanoate was the most effective phorbol ester against the snails. It killed both species $\left(\mathrm{LC}_{100}\right.$ ) at a concentration of $10 \mathrm{mg} / \mathrm{mL}$. One disadvantage of this method is the requirement of a large volume of the test substances because the assay must to be performed in $100 \mathrm{~mL}$ Petri dishes. However, the assay using snails continues to be used 
and is sometimes combined with HPLC detection and quantification steps. Another species that was tested for PE toxicity was Physa fontinalis, which was sensitive to $0.1 \mathrm{mg} / \mathrm{L}(6.7 \%$ mortality) PE-rich extract, and the $\mathrm{LC}_{100}$ was reported as $\left.1 \mathrm{mg} / \mathrm{mL}[93,102]\right)$. The variation in PE sensitivity among the snails may be related to species-specific PE sensitivity and/or different chemical properties of the PEs. In addition to testing for PE activity against host snails, the susceptibility of the parasite Schistosoma mansoniwas also assayed [103]. This test had the advantage of requiring a small volume of test substance. The PE-rich methanol extract from $J$. curcas crude oil that was obtained by pressing the seeds was able to kill all the cercarie $\left(\mathrm{LC}_{100}\right)$ at a concentration of $25 \mathrm{mg} / \mathrm{mL}$.

The efficacy of phorbol esters against insects has been shown recently. Termites (Odontotermes obesus) were used as a target to test PE toxicity [104]. Because it was necessary to use HPLC to isolate and quantify PE from J. curcas seeds, they tested different concentrations of PE (500-5 mg/mL) over a period of 1 to 72 hours. The $\mathrm{LC}_{100}$ was determined after 72 hours of treatment using $5 \mathrm{mg} / \mathrm{mL}$ of PE. However, to decrease the assay time, it was necessary to use higher concentrations of PE. To obtain the $\mathrm{LC}_{100}$ after 12 hours of treatment, they used $500 \mathrm{mg} / \mathrm{mL}$ of PE. Another study using insects was recently performed by Devappa et al. [105]. They tested a PE-enriched fraction (PEEF) against Spodoptera frugiperda and the mortality was evaluated 24 hours after treatment with different concentrations of PEEF. A minimum mortality (20\%) was reached using $0.5 \mathrm{mg} / \mathrm{mL}$ PEEF and a maximum of $80 \%$ mortality was observed with $2 \mathrm{mg} / \mathrm{mL}$ PEEF. The sensitivity to PEs of both species (O. obesus and $S$. frugiperda) is not very different, and this assay showed that PEs can be used as an insecticide and that insects are good models for detecting the toxic activity of PEs.

Some crustaceans are widely used as toxicity indicators in bioassay systems. Phorbol ester toxicity has previously been assayed to Artemia salina and Daphnia magna [83]. The advantages of using A. salina in toxicological assays were demonstrated by Ruebhart et al. [106]. These advantages include wide commercial availability of the cysts, easy storage, maintenance and hatching of the cysts, the assay is cost effective, simple, rapid and sensitive, less test samples are required, the assays can be performed in 96-well microplates and meets the ethical animal treatment guidelines of many countries. The best PE induced mortality rate $(72 \%)$ was observed using a concentration of $47 \mathrm{mg} / \mathrm{mL}$ [83]. Increasing the concentration did not effectively improve the mortality rate because $6000 \mathrm{mg} / \mathrm{mL}$ of PE was needed to reach $100 \%$ mortality. Different types of PEs were previously tested against A. salina [107] and there was variation in the mortality rates to each PE. This reinforces the role of the PE chemical structure and purity with regard to toxicity. The first toxicological assay of PEs from J. curcas using Daphnia magna showed that these crustaceans are more sensitive to PEs than A. salina [83]. The $\mathrm{LC}_{100}$ was only $3 \mathrm{mg} / \mathrm{mL}$, and the lowest effective concentration, which induced $26 \%$ mortality, was $0.5 \mathrm{mg} / \mathrm{mL}$. Although snails were more sensitive to PEs than crustaceans, the use of $A$. salina and D. magna is preferred for assaying a large number of PE samples because the test can be performed in 96-well plates.

Similar to the molluscicidal, insecticidal and antiparasitic activity, PE toxicity against microorganisms was also reported. It was demonstrated that phorbol esters from Sapium indicum had antibacterial activity [108]. Six bacteria genera were recently tested for PE toxicity. The 
maximum concentration of PE-rich extract for each bacterium tested was $537 \mu \mathrm{g} / \mathrm{mL}$ for $\mathrm{Ba}$ cillus subtillis, $250.7 \mu \mathrm{g} / \mathrm{mL}$ for Pseudomonas putida, $215 \mu \mathrm{g} / \mathrm{mL}$ for Proteus mirabilis, 394 $\mu \mathrm{g} / \mathrm{mL}$ for Staphylococcus aureus, $215 \mu \mathrm{g} / \mathrm{mL}$ for Streptococcus pyogenes and $465.7 \mu \mathrm{g} / \mathrm{mL}$ for Escherichia coli [83]. Compared with the other biological assays presented here, the use of bacteria to detect the toxic activity of PEs is not very effective because the sensitivity is much higher than those reported for D. magna. The use of PEs as an antibacterial agent was also not as effective compared with the other compounds. The antifungal activity of $J$. curcasPEs extracted from residual cake has previously been tested [83, 109]. The toxicity of the PE-rich extract (from Jatropha cake) against Fusarium oxysporum, Pythiumaphani dermatum, Lasiodiplodia theobromae, Curvularia lunata, Fusariums emitectum, Colletotrichum capsici and Colletotrichum gloeosporioides was assayed and the concentrations that inhibited $100 \%$ of mycelial growth was 6, 3, 6, 5, 3, 4and $10 \mathrm{mg} / \mathrm{L}$, respectively. Although a high concentration of PEs was required to reach $100 \%$ inhibition, they used $500 \mu \mathrm{g} / \mathrm{mL}$ PEsand reported minimum mycelial growth inhibition values for each species [109]. Another PE-rich extract toxicity study using fungi was recently reported [83]. In this study, it was demonstrated that of seven species of fungi, the most sensitive to PE toxicity were Botrytis cinerea, Fusarium oxysporum and Fusarium moniliforme and $100 \%$ inhibition was achieved at a concentration of $114.6 \mu \mathrm{g} / \mathrm{mL}$. The other four species tested, Aspergillus niger, Aspergillus flavus, Curvularia lunata and Penicillium notatum, were less susceptible to PE toxicity and $100 \%$ inhibition was reached using $143.3 \mu \mathrm{g} / \mathrm{mL}$. Antimicrobial tests using bacteria and fungi efficiently detect PE toxic activity and could be used for quality control to determine the effectiveness of Jatropha cake detoxification processes.

Because PEs are activators of protein kinase C (PKC), a biochemical assay to detect PEs based on this property was described [110]. In this method, PKC is incubated with Mg-ATP and a synthetic peptide which is labelled with a fluorescent dye. When a PKC activator is present, the active enzyme phosphorylates the peptide. When the reaction mixture is separated by electrophoresis, the phosphorylated peptide becomes negatively charged and migrates to the positive pole. The fluorescently labelled peptide can then be quantified by densitometric analysis. This assay was used by Wink et al. [110] to determine the activity of PEs sequestered by Pachycoris klugii. The positive control (12-O-tetradecanoylphorbol-13acetate) was used at a concentration of $\sim 6 \mu \mathrm{g} / \mathrm{mL}$ and indicated that this activity assay is very sensitive. Because of the high sensitivity and availability of commercial PKC activity assay kits, this method could be used for the rapid and efficient detection of PEs in detoxified Jatropha cake.

Although many methods have been described to detect Jatropha curcas phorbol esters, these biological tests are not specific to PEs. In contrast to ricin detection assays that can combine biological assays with antibody recognition [59, 63, 64], PEs cannot be tested with this methodology. The best method to test for PEs is to continue using HPLC analysis followed by a biological test. The most well-established biological assay is the assay using snails, which has previously been used as a quality control for Jatropha cake detoxification [83, 103]. Although several of the in vitro assays, such as PKC activity and toxicity against microorganisms are more sensitive, they were not used for this purpose, and additional studies are necessary. 


\section{Conclusion}

Currently, several processes to detoxify castor bean and Jatropha cakes have been developed however, it is essential to choose a method that is universally accepted to validate such processes of detoxification. The literature indicates that the method to be used to evaluate the toxicity of castor cake is different from what should be used for jatropha cake.

Among the different methods that can be used to assess the presence of ricin some are more suitable to control attacks bioterrorist. They are sensitive methods that detect the presence of ricin, but need not evaluate the biological activity.

In this review, methods based on Vero cell viability are best suited to validate the processes of castor cake detoxification. Vero cells, epithelial cell line isolated from African green monkey are indicated since these cells maintain cell organelles characteristics and stable structure when in contact with the cake detoxified. Evaluation procedures for Jatropha are still under development. The detection of phorbol esters by reverse phase chromatography, associated with toxicity tests on snails are recommended.

\section{Author details}

Keysson Vieira Fernandes and Olga Lima Tavares Machado

Universidade Norte Fluminense - Darcy Ribeiro (UENF), Brazil

\section{References}

[1] Santos RF, Barros MAL, Marques FM, Firmino PT, Requião LEG. Análise Econômica. In: Azevedo DM, Lima EF (ed). O Agronegócio da Mamona no Brasil. Campina Grande: Embrapa; 2001. p17-35.

[2] Savy Filho A. Mamona: Tecnologia Agrícola. Campinas: EMOPI; 2005.

[3] Kumar A, Sharma S. An evaluation of multipurpose oil seed crop for industrial uses (Jatropha curcas L.): A review. Industrial Crops and Products 2008; 28(1): 1-10.

[4] Spies JR, Coulson EJ. The chemistry of allergens VIII. Isolation and properties of an active protein-polysaccharidic fraction, CB-1A, from castor bean. Journal of the American Chemical Society 1973; 65(9): 1720-1725.

[5] Maciel FM, Laberty MA, Oliveira ND, Felix SP, Soares AMS, Verícimo MA, Machado, OLT. A new $2 S$ albumin from Jatropha curcas L. seeds and assessment of its allergenic properties. Peptides 2009; 30(12): 2103-2107. 
[6] Perrone JC, Iachan A, Domont GB, Disitzer LV, Castro VRO, Roitman R, Gomes SM. Contribuição ao estudo da torta de mamona. Rio de Janeiro: Departamento de Imprensa Nacional; 1966.

[7] Olsnes S. The history of ricin, abrin and related toxins. Toxicon 2004; 44(4): 361-370.

[8] Olsnes S, Wesche J, Falsnes PO. Binding, uptake, routing and translocation of toxins with intracellular sites of action. In: Alouf JE, Freer JH (ed). The Comprehensive Sourcebook of Bacterial Toxins. London: Academic Press; 1999. p73-93.

[9] Endo Y, Mitsui K, Motizuki M, Tsurugi K. The mechanism of action of ricin and related toxic lectins on eukaryotic ribosomes. The site and the characteristics of the modification in $28 \mathrm{~S}$ ribosomal RNA caused by the toxins. Journal of Biological Chemistry 1987; 262(12): 5908-5912.

[10] Youle RJ, Murray GJ, Neville DM. Studies on the galactose binding site of ricin and the hybrid toxin man6p-ricin. Cell 1981; 23(2): 551-559.

[11] Stirpe F, Batelli MG. Review: Ribosome-inactivating proteins: progress and problems. Cellular and Molecular Life Sciences 2006; 63(16): 1850-1866.

[12] Olsnes S, Fernandez-Puemtes C, Carrasco L, Vazquez D. Ribosome inactivation by the toxic lectins abrin and ricin. Kinetics of the enzymatic activity of the toxin Achains. European Journal of Biochemistry 1975; 60(1): 281-288.

[13] Atlas RM. Bioterrorism: from threat to reality. Annual Review of Microbiology 2002; 56: 167-185.

[14] Deus-de-Oliveira N, Machado OLT. Allergens and toxins of oleaginous plants: problems and solutions. In: Bernardes MAS (ed). Environmental Impact of Biofuels. Rijeka: InTech; 2011. p41-66.

[15] Koja N, Shibata T, Mochida K. Enzyme-linked immunoassay of ricin. Toxicon 1980; 18(5-6): 611-618.

[16] Godal A, Olsnes S, Pihl AJ, Radioimmunoassays of ricin and abrin in blood. Journal of Toxicology and Environmental Health 1981; 8(3): 409-417.

[17] Ramakrishnan S, Eagle MR, Houston LL. Radioimmunoassay of ricin A- and Bchains applied to samples of ricin A-chain prepared by chromatofocusing and by DEAE Bio-Gel A chromatography. Biochimica et Biophysica Acta 1982; 719(2): 341-348.

[18] Poli MA, Rivera VR, Hewetson JF, Merrill GA. Detection of ricin by colorimetric and chemiluminescence ELISA. Toxicon 1994; 32(11): 1371-1377.

[19] Shyu HF, Chiao DJ, Liu HW, Tang SS. Monoclonal antibody-based enzyme immunoassay for detection of ricin. Hybrid Hybridomics 2002; 21(1): 69-73.

[20] Garber EAE, Eppley RM, Stack ME, McLaughlin MA, Park DL. Feasibility of immunodiagnostic devices for the detection of ricin, amanitin, and T-2 toxin in food. Journal of Food Protection 2005; 68(6): 1294-1301. 
[21] Ogert RA, Brown JE, Singh BR, Shriver-Lake LC, Ligler FS. Detection of Clostridium botulinum toxin A using a fiber optic-based biosensor. Analytical Biochemistry 1992; 205(2): 306-312.

[22] Ogert RA, Shriver-Lake LC, Ligler FS. Toxin detection using a fiber optic-based biosensor. In: Lakowics JR, Thompson RB (ed). Advances in Fluorescence Sensing Technology; 1993. p11-17.

[23] Narang U, Anderson GP, Ligler FS, Buranst J. Fiber optic-based biosensor for ricin. Biosensors \& Bioelectronics 1997; 12(9-10): 937-945.

[24] Shyu RH, Shyu HF, Liu HW, Tang SS. Colloidal gold-based immune-chromatographic assay for detection of ricin. Toxicon 2002; 40(3): 255-258.

[25] Thullier P, Griffiths G. Broad recognition of ricin toxins prepared from a range of Ricinus cultivars using immune-chromatographic tests. Clinical Toxicology 2009; 47(7): 643-650.

[26] Gatto-Menking DL, Yu H, Bruno JG, Goode MT, Miller M, Zulich AW. Sensitive detection of biotoxoids and bacterial spores using an immunomagnetic electrochemiluminescece sensor. Biosensors \& Bioeletronics 1995; 10(6-7): 501-507.

[27] Yu H, Raymonda JW, McMahon TM, Campagnari AA. Detection of biological threat agents by immunomagnetic microsphere-based solid phase fluorogenic- and electrochemiluminescence. Biosensors \& Bioelectronics 2000; 14(10-11): 829-840.

[28] Shankar K, Zeng K, Ruan C, Grimes CA. Quantification of ricin concentrations in aqueous media. Sensors and Actuators B 2005; 107(2): 640-648.

[29] Wadkins RM, Golden JP, Pritsiolas LM, Ligler FS. Detection of multiple toxic agents using a planar array immunosensor. Biosensors \& Bioelectronics 1998; 13(3-4): 407-415.

[30] Delehanty JB, Ligler FS. A microarray immunoassay for simultaneous detection of proteins and bacteria. Analytical Chemistry 2002; 74(21): 5681-5687.

[31] Weingart OG, Gao H, Crevoisier F, Heitger F, Avondet MA, Sigrist H. A bioanalytical platform for simultaneous detection and quantification of biological toxins. Sensors 2012; 12(2): 2324-2339.

[32] Sano T, Smith CL, Cantor CR. Immune-PCR: very sensitive antigen detection by means of specific antibody-DNA conjugates. Science 1992; 258(5079): 120-122.

[33] Lubelli C, Chatgiglialoglu A, Bolognesi A, Strocchi P, Colombatti M, Stirpe F. Detection of ricin and other ribosome-inactivating proteins by an immune-polymerase chain reaction assay. Analytical Biochemistry 2006; 355(1): 102-109.

[34] He X, McMahon S, Henderson TD, Griffey SM, Cheng LW. Ricin toxic kinetics and its sensitive detection in mouse sera or feces using immune-PCR. Plos One 2010; 5(9): e12858. doi: 10.1371/journal.pone.0012858. 
[35] Fredriksson SA, Hulst AG, Artursson E, Jong AL, Nilsson C, Baar BLM. Forensic identification of neat ricin and of ricin from crude castor bean extracts by mass spectrometry. Analytical Chemistry 2005; 77(6): 1545-1555.

[36] Duriez E, Fenaille F, Tabet JC, Lamourette P, Hilaire D, Becher F, Ezan E. Detection of ricin in complex samples by immunocapture and matrix-assisted laser desorption/ ionization time-of-flight mass spectrometry. Journal of Proteome Research 2008; 7(9): 4154-4163.

[37] Kull S, Pauly D, Störmann B, Kirchner S, Stämmler M, Dorner MB, Lasch P, Naumann D, Dorner BG. Multiplex detection of microbial and plant toxins by immunoaffinity enrichment and matrix-assisted laser desorption/ionization mass spectrometry. Analytical Chemistry 2010; 82(7): 2916-2924.

[38] James W. Aptamers. In: Meyers RA (ed). Encyclopedia of Analytical Chemistry; 2000. p4848-4871.

[39] Kirby R, Cho EJ, Gehrke B, Bayer T, Park YS, Neikirk DP, Mc Devitt JT, Ellington AD. Aptamer-based sensor assay for the detection and quantitation of proteins. Analytical Chemistry 2004; 76(14): 4066-4075.

[40] Cho EJ, Collett JR, Szafranska AE, Ellington AD. Optimization of aptamer microarray technology for multiple protein targets. Analytica Chimica Acta 2006; 564(1): 82-90.

[41] Haes AJ, Giordano BC, Collins GE. Aptamer-based detection and quantitative analysis of ricin using affinity probe capillary electrophoresis. Analytical Chemistry 2006; 78(11): 3758-3764.

[42] Winterbottom DA, Naraynaswamy R, Raimundo Jr IM. Cholesteric liquid crystals for detection of organic vapours. Sensors and Actuators B 2003; 90(1-3): 52-57.

[43] Zhao YB, Yu JH, Zhao HF, Tong CY, Wang PH. A novel method for label-free detection of ricin using liquid crystals supported on chemically functionalized surfaces. Sensors and Actuators B 2011; 155(1): 351-356.

[44] Anandan S, Anil Kumar GK, Ghosh J, Ramachandra KS. Effect of different physical and chemical treatments on detoxification of ricin in castor cake. Animal Feed Science and Technology 2005; 120(1-2): 159-168.

[45] Godoy MG, Gutarra MLE, Maciel FM, Felix SP, Bevilaqua JV, Machado OLT, Freire DMG. Use of a low-cost methodology for biodetoxification of castor bean waste and lipase production. Enzyme and Microbial Technology 2009; 44(5): 317-322.

[46] Lugnier AAJ, Le Meur MA, Gerlinger P, Dirheimer G. Inhibition of in vitro protein synthesis in a rabbit reticulocyte cell-free system by toxic tryptic peptides from ricin. Biochimie 1974; 56(9): 1287-1289.

[47] Barbieri L, Bolognesi A, Cenini P, Falasca AI, Minghetti A, Garofano L, Guicciardi A, Lappi D, Miller SP, Stirpe F. Ribosome-inactivating proteins from plant cells in culture. Biochemical Journal 1989; 257(3): 801-807. 
[48] Langer M, Rothe M, Eck J, Möckel B, Zinke H. A nonradioactive assay for ribosomeinactivating proteins. Analytical Biochemistry 1996; 243(1): 150-153.

[49] Mei Q, Fredrickson CK, Lian W, Jin S, Fan ZH. Ricin detection by biological signal amplification in a well-in-a-well device. Analytical Chemistry 2006; 78(22): 7659-7664.

[50] Zamboni M, Brigotti M, Rambelli F, Montanaro L, Sperti S. High-pressure-liquidchromatography and fluorimetric methods for the determination of adenine released from ribosomes by ricin and gelonin. Biochemistry Journal 1989; 259(3): 639-643.

[51] Heisler I, Keller J, Tauber R, Sutherland M, Fuchs H. A colorimetric assay to quantitation of free adenine applied to determine the enzymatic activity of ribosome inactivating proteins. Analytical Biochemistry 2002; 302(1): 114-122.

[52] Keener WK, Rivera VR, Young CC, Poli MA. An activity-dependent for ricin and related RNA N-glycosidase based on electrochemiluminescence. Analytical Biochemistry 2006; 357(2): 200-207.

[53] Cho YC, Keener WK, Garber EAE. Application of deadenylase electrochemiluminescence assay for ricin to food in a plate format. Journal of Food Protection 2009; 72(4): 903-906.

[54] Keener WK, Rivera VR, Cho CY, Hale ML, Garber EAE, Poli MA. Identification of the RNA N-glycosidase activity of ricin in castor bean extracts by an electrochemiluminescence-based assay. Analytical Biochemistry 2008; 378(1): 87-89.

[55] Hines HB, Brueggemann EE, Hale ML. High-performance liquid chromatographymass selective detection assay for adenine released from a synthetic RNA substrate by ricin A chain. Analytical Biochemistry 2004; 330(1): 119-122.

[56] Becher F, Duriez E, Volland H, Tabet JC, Ezan E. Detection of functional ricin by immunoaffinity and liquid chromatography-tandem mass spectrometry. Analytical Chemistry 2007; 79(2): 559-565.

[57] Kalb SR, Barr JR. Mass spectrometric detection of ricin and its activity in food and clinical samples. Analytical Chemistry 2009; 81(6): 2037-2142.

[58] Li XP, Bericevic M, Saidasan H, Tumer NE. Ribosome depurination is not sufficient for ricin-mediated cell death in Saccharomyces cereviseae. Infection and Immunity 2007; 75(1): 417-428.

[59] Brzezinski JL, Craft DL. Evaluation of an in vitro bioassay for the detection of purified ricin and castor bean in beverages and liquid food matrices. Journal of Food Protection 2007; 70(10) 2377-2382.

[60] Sehgal P, Khan M, Kumar O, Vijayaraghavan R. Purification, characterization and toxicity profile of ricin isoforms from castor beans. Food and Chemical Toxicology 2010; 48(11): 3171-3176. 
[61] Sehgal P, Kumar O, Kameswararao M, Ravindran J, Khan M, Sharma S, Vijayaraghavan R, Prasad GBKS. Differential toxicity profile of ricin isoforms correlates with their glycosilation levels. Toxicology 2011; 282(1-2): 56-67.

[62] Khalil CN, Leite L. Process for producing biodiesel fuel using triglyceride-rich oleaginous seed directly in a transesterification reaction in the presence of an alkaline alkoxyde catalyst. US Patent 7, 112, 229; 2006.

[63] Godoy MG, Fernandes KV, Gutarra MLE, Melo EJT, Castro AM, Machado OLT, Freire DMG. Use of Vero cell line to verify the biodetoxification efficiency of castor bean waste. Process Biochemistry 2012; 47(4): 578-584.

[64] Fernandes KV, Deus-de-Oliveira N, Godoy MG, Guimarães ZAS, Nascimento VV, Melo EJT, Freire DMG, Dansa-Petretski M, Machado OLT. Simultaneous allergen inactivation and detoxification of castor bean cake by treatment with calcium compounds and solid-state fermentation. Brazilian Journal of Medical and Biological Research 2012; 45 in press.

[65] Stirpe F, Pession-Brizzi , Lorenzoni E, Strocchi P, Motanato L, Sperti S. Studies on the proteins of the seeds of Croton tiglium and Jatropha curcas. Biochemical Journal 1976; 156(1): 1-6.

[66] Qin W, Ming-Xing H, Ying X, Xin-Shen Z, Fang C. Expression of a ribosome inactivating protein (curcin 2) in Jatropha curcas is induced by stress. Journal of Biosciences 2005. 30(3): 351-357.

[67] Lin J, Chen Y, Xu Y, Yan F, Tang L, Chen F. Cloning and expression of curcin, a ribosome-inactivating protein from the seeds of Jatropha curcas. Acta Botânica Sinica 2003; 45(7): 858-863.

[68] Adam SEI, Magzoub M. Toxicity of Jatropha curcas for goats. Toxicology 1975; 4(3): 388-389.

[69] Ahmed OMM, Adam SEI. Toxicity of Jatropha curcas in sheep and goats. Research in Veterinary Science 1979; 27(1): 89-96.

[70] Abdu-Aguye I, Sannusi A, Alafiya-Tayo RA, Brusnurmath SR. Acute toxicity studies with Jatropha curcas L. Human Toxicology 1986; 5(4): 269-274.

[71] El Badwi SMA, Mousa HM, Adam SEI, Hapke HJ. Response of Brown Hissex chicks to low levels of Jatropha curcas, Ricinus communis or their mixture. Veterinary \& Human Toxicology 1992; 34: 304-306.

[72] El Badwi SMA, Adam SEI, Hapke HJ. Comparative toxicity of Ricinus communis and Jatropha curcas in Brown Hissex chicks. Deutsch Tierarztl Wochenchr 1995; 102: 75-77.

[73] Beutler JA, Ada AB, McCloud TG, Cragg GM. Distribution of phorbol ester bioactivity in the euphorbiaceae. Phytoterapic Response 1989; 3(5): 188-192.

[74] Goel G, Makkar HPS, Francis G, Becker K. Phorbol esters: Structure, biological activity and toxicity in animals. International Journal of Toxicology 2007; 26(4): 279-288. 
[75] Clemens MJ, Tryner I, Menaya J. The role of protein kinase C isoenzymes in the regulation of cell proliferation and differentiation. Journal of Cell Science 1992; 103(4): 881-887.

[76] Brodie C, Blumberg PM. Regulation of cell apoptosis by protein kinase C. Apoptosis 2003; 8(1): 19-27.

[77] Adolf HJ, Opferkuch J, Hecker E. Irritant phorbol derivates from four Jatropha species. Phytochemistry 1948; 23(1): 129-132.

[78] Rakshit KD, Darukeshwara J, Rathina Raj K, Narasimhamurthy K, Saibaba P, Bhagya S. Toxicity studies of detoxified Jatropha meal (Jatropha curcas) in rats. Food and Chemical Toxicology 2008; 46(12): 3621-3625.

[79] Li CY, Devappa RK, Liu JX, Lv JM, Makkar HPS, Becker K. Toxicity of Jatropha curcas phorbol esters in mice. Food and Chemical Toxicology 2010; 48(2): 620-625.

[80] Makkar HPS, Becker K, Sporer F, Wink M. Studies of nutritive potential and toxic constituents of differents provenances of Jatropha curcas. Journal of Agricultural and Food Chemistry 1997; 45(8): 3152-3157.

[81] Makkar HPS, Oderibigbe AO, Becker K. Comparative evaluation of non-toxic and toxic varieties of Jatropha curcas for chemical composition, digestibility, protein degradability and toxic factors. Food Chemistry 1998; 62(2): 207-215.

[82] Makkar HPS, Siddhuraju P, Becker K. A laboratory manual on quantification of plant secondary metabolites. New Jersey: Humana Press; 2007. p130.

[83] Devappa RK, Rajesh SK, Kumar V, Makkar HPS, Becker K. Activities of Jatropha curcas phorbol esters in various bioassays. Ecotoxicology and Environmental Safety 2012; 78: 57-62.

[84] Martínez-Herrera J, Siddhuraju P, Francis G, Dávila-Ortíz G, Becker K. Chemical composition, toxic/antimetabolic constituents, and effects of different treatments on their levels, in four provenances of Jatropha curcas L. from Mexico. Food Chemistry 2006; 96(1): 80-89.

[85] Devappa RK, Swamylingappa B. Biochemical and nutritional evaluation of Jatropha protein isolate prepared by steam injection heating for reduction of toxic and antinutritional factors. Journal of the Science of Food and Agriculture 2008; 88(5): 911-919.

[86] Joshi C, Mathur P, Khare SK. Degradation of phorbol esters by Pseudomonas aeruginosa PseA during solid-state fermentation of deoiled Jatropha curcas seed cake. Bioresource Technology 2011; 102(7): 4815-4819.

[87] Barros CRM, Ferreira LMM, Nunes FM, Bezerra RMF, Dias AA, Guedes CV, Cone JW, Marques GSM, Rodrigues MAM. The potential of white-rot fungi to degrade phorbol esters of Jatropha curcas L. seed cake. Engineering in Life Sciences 2011; 11(1): 107-110. 
[88] Phasukarratchai N, Tontayakom V, Tongcumpou C. Reduction of phorbol esters in Jatropha curcas L. pressed meal by surfactant solutions extraction. Biomass and Bioenergy 2012; 45: 48-56.

[89] Haas W, Sterk H, Mittelbach M. Novel 12-deoxy-16-hydroxiphorbol diester isolated from the seed oil of Jatropha curcas. Journal of Natural Products 2002; 65: 1434-1440.

[90] Basha SD, Francis G, Makkar HPS, Becker K, Sujatha M. A comparative study of biochemical traits and molecular markers for assessment of genetic relationships between Jatropha curcas L. germoplasm from different countries. Plant Science 2009; 176(6): 812-823.

[91] He W, King AJ, Khan MA, Cuevas JA, Ramiaramanana D, Graham IA. Analysis of seed phorbol-ester and curcin content together with genetic diversity in multiple provenances of Jatropha curcas L. from Madagascar and Mexico. Plant Physiology and Biochemistry 2011; 49(10): 1183-1190.

[92] Makkar HPS, Maes J, Greyt WD. Removal and degradation of phorbol esters during pre-treatment and transesterification of Jatropha curcas oil. Journal of the American Oil Chemist's Society 2009; 86(2): 173-181.

[93] Devappa RK, Makkar HPS, Becker K. Optimization of conditions for the extraction of phorbol esters from Jatropha oil. Biomass and Bioenergy 2010; 34(8): 1125-1133.

[94] Ichihashi K, Yuki D, Kurokawa H, Igarashi A, Yajima T, Fujiwara M, Maeno K, Sekiguchi S, Iwata M, Nishino H. Dynamic analysis of phorbol esters in the manufacturing process of fatty acid methyl esters from Jatropha curcas seed oil. Journal of the American Oil Chemist's Society 2011; 88(6): 851-861.

[95] Katole S, Saha SK, Sastry VRB, Lade MH, Prakash B. Intake, blood metabolites and hormonal profile in sheep fed processed Jatropha (Jatropha curcas) meal. Animal Feed Science and Technology 2011; 170(1-2): 21-26.

[96] Wang H, Chen Y, Zhao Y, Liu H, Liu J, Makkar HPS, Becker K. Effects of replacing soybean meal by detoxified Jatropha curcas kernel meal in the diet of growing pigs on their growths, serum biochemical parameter and visceral organs. Animal Feed Science and Technology 2011; 170(1): 141-146.

[97] Becker K, Makkar HPS. Effects of phorbol esters in carp (Cyprinus carpio L.). Veterinary $\mathcal{E}$ Human Toxicology 1998; 40(2): 82-86.

[98] Kumar V, Akinleye AO, Makkar HPS, Angulo-Escalante MA, Becker K. Growth performance and metabolic efficiency in the Nile tilapia (Oreochromis niloticus L.) fed on a diet containing Jatropha platyphylla kernel meal as a protein source. Journal of Animal Physiology and Animal Nutrition 2012; DOI: 10.1111/j.1439-0396.2010.01118.x.

[99] Yasuraoka K, Hashiguchi J, Blas BL. Laboratory assessment of the molluscicidal activity of the plant Jatropha curcas against Oncomelania snail. Proceedings of the Philippine-Japan joint conference onschistosomiasis research and control. Manila: 1980. p110-112. 
[100] El Kheir YM, El Tohami MS. Investigation of moluscicidall activity of certain Sudanese plants used in folk-medicine. Journal of Tropical Medicine and Hygiene 1979; 82(11-12): 237-241.

[101] Liu SY, Sporer F, Wink M, Jourdane J, Henning R, Li YL, Ruppel A. Anthraquinones in Rheum palmatum and Rumex dentatus (Polygonaceae), and phorbol esters in Jatropha curcas (Euphorbiaceae) with molluscicidal activity against the schistosome vector snails Oncomelania, Biomphalaria and Bulinus. Tropical Medicine and International Health 1997; 2(2): 179-188.

[102] Devappa RK, Makkar HPS, Becker K. Biodegradation of Jatropha curcas phorbol esters in soil. Journal of the Science of Food and Agriculture 2010; 90(12): 2090-2097.

[103] Rug M, Ruppel A. Toxic activities of the plant Jatropha curcas against intermediate snail hosts and larvae of schistosomes. Tropical Medicine and International Health 2000; 5(6): 423-430.

[104] Verma M, Pradhan S, Sharma S, Naik SN, Prasad R. Efficacy of karanjin and phorbol ester against termites (Odontotermes obesus). International Biodeterioration \& Biodegradation 2011; 65(6): 877-882.

[105] Devappa RK, Angulo-Escalante MA, Makkar HPS, Becker K. Potential of using phorbol esters as an insecticide against Spodoptera frugiperda. Industrial Crops and Products 2012; 38: 50-53.

[106] Ruebhart DR, Cock IE, Shaw GR. Brine shrimp bioassay: importance of correct taxonomic identification of Artemia (Anostraca) species. Environmental Toxicology 2008; 23(4): 555-560.

[107] Kinghom AD, Harjes KK, Doorenbos NJ. Screening procedure for phorbol ester using brine shrimp (Artemia salina) larvae. Journal of Pharmaceutical Sciences 1977; 66(9): 1362-1363.

[108] Chumkaew P, Karalai C, Ponglimanon C, Chantraprommat C. Antimycobacterial Activity of phorbol esters from the fruits of Sapium indicum. Journal of Natural Products 2003; 66(4): 540-543.

[109] Saetae D, Santornsuk W. Antifungal activities of ethanolic extract from Jatropha curcas seed cake. Journal of Microbiology and Biotechnology 2009; 20(2): 319-324.

[110] Wink M, Grimm C, Koschmiedes C, Sporer F, Bergeot O. Sequestration of phorbol esters by the aposematically coloured bug Pachycoris klugii (Heteroptera: Scutelleridae) feeding on Jatropha curcas (Euphorbiaceae). Chemoecology 2000 ; 10(4): 179-184. 